\title{
Soekarno: \\ His Mannerism and Method of Communication
}

\author{
Justin Wejak
}

\begin{abstract}
The main purpose of this article is to discuss Soekarno's mannerism and method of communication. Certain aspects such as Soekarno's use of language in his speeches are highlighted here in order to provide some basic understanding of Soekarno - both as a person and a political leader of the nation. The article aims at stimulating further discussions concerning this very well known leader. This article also examines Soeharto's style of speech for a comparison.
\end{abstract}

Keywords: communication, language, power, charisma, monologue, dialogue, politics, personality, culture, religion, revolution.

\section{Introduction}

The inaugural leader of the Republic of Indonesia, President Soekarno, is undoubtedly one of the greatest examples of charisma ${ }^{1}$ the world has ever known. For twenty years as the archipelago's revolutionary leader and twenty years as the President of Indonesia, Soekarno used the power ${ }^{2}$ of language ${ }^{3}$ and his charismatic appeal for political gain and national advancement. While it is easy to tell who has charisma and who never will, it is very difficult to define this quality possessed by those who inspire us. Soekarno's charisma was evident in his cellubrious sexual allure and ability, like Mahatma Gandhi, Nelson Mandela and Xanana Gusmao, to mesmerize a mass audience with a combination of passion, ideas and personality (Porter \& Williams, 1999, p. 8).

According to John Howard's biographer, David Barnett, 'the concept of charisma is one of the most dangerous concepts in a democracy that you can find. Charisma is a sort of totalitarian, fascist shorthand for policy and program. To talk about electing people because you like them as if they are film stars strikes at the fundamentals of the way the system works. The responsibility of a people is to elect a government that will

\footnotetext{
${ }^{1}$ According to the Oxford Encyclopedic English Dictionary, the term charisma (pl. charismata) means [a] the ability to inspire followers with devotion and enthusiasm. [b] an attractive aura; great charm. [c] a divinely conferred power or talent.

2 In the Oxford Encyclopedic English Dictionary, the word power is defined as [a] the ability to do or act. [b] a particular faculty of body or mind. [c] government, influence, or authority. [d] political or social ascendancy or control. [e] authorization; delegated authority. [f] personal ascendancy. $[\mathrm{g}$ ] an influential person, group, or organization.

${ }^{3}$ Language, according to the Oxford Encyclopedic English Dictionary, is [a] the method of human communication, either spoken or written, consisting of the use of words in an agreed way. [b] the language of a particular community or country etc. [c] the faculty of speech; a style or the faculty of expression; the use of words, etc. [d] any method of expression.
} 
govern responsibly. For people to be beguiled by popularity for its own sake, to choose someone who makes them feel good, is dangerous in the extreme. To my mind, the most charismatic personality in history was undoubtedly Adolf Hitler' (Porter \& Williams, 1999, p. 8).

How right Barnett was in assessing the charismatic appeal of Hitler. And the same can invariably be said for Soekarno, although not to the same extent. Given Soekarno's Javanese background and the fact that he orchestrated the archipelago's revolution which led to the attainment of Indonesian independence, the people were beguiled by his popularity and charm and chose him because he made them feel good. The amount of choice the people had, however, was certainly arguable. Charisma implies physical presence combined with an ability to persuade. Charisma and great talk go together. But the chat has to be quality. Otherwise, silence is more effective.

\section{A Leader is Born}

Soekarno was brought up in a purely Javanese, old style environment which embraced fairly tales and represented a climate of make-believe. This, perhaps, sounds rather simplistic in academic context, however, one should bear in mind that Javanese belief systems are indeed very complex, like all belief systems are. Soekarno never escaped this grounding and it influenced his whole life, his whole thinking, his soul and his longings. His grandparents even believed he had supernatural powers and was predestined to be a great leader.

As a boy, Soekarno thought he would some day be the hero of his people. And he was just that for a period of time. He conjured up all kinds of happenings in which he played the hero. He believed he was capable of doing some wonderful and extraordinary things so that the eyes of not only his nation but the world would look at him, admire him and applaud him. ${ }^{4}$ Soekarno yearned for the hero's welcome given by the Romans to Julius Caesar on his return from the battles of Gallia and to Prince Gadjah Mada, from the Kingdom of Majapahit in East Java, following his defeat of the strong Kingdom of Padjadjaran in West Java. ${ }^{5}$

The belief in his destiny was so strong in him that it was a constant impetus in his drive for power. And it was this dramatic and theatrical appeal which helped him retain the presidency for more than twenty years. His burning ambition was to be the first man in his country capable of enduring the bitter pills fate would force him to swallow.

\section{The Revolution ${ }^{6}$ Beckons}

\footnotetext{
4 Soekarno was referring here to the Battle of Surabaya (November 1945) in which heavily armed British troops aided by planes and artillery met fierce resistance from the lightly armed Indonesian irregulars.

5 Gadjah Mada was the Prime Minister of the Kingdom of Majapahit which was centred in East Java and at the zenith of its power during the fourtheenth century controlled large parts of the present Indonesian and Southeast Asia.

6 In the Oxford Encyclopeddic English Dictionary, revolution means [a] the forcible overthrow of a government or social order, in favour of a new system. [b] any fundamental change or reversal of conditions. [c] the act or an instance of revolving.
} 
During the 1920s, Soekarno was already dreaming of his great destiny which was to be the man in Indonesia to unite the beliefs of all the people. He would like to unite the religious people, the Nationalists and the Marxists in one big force. He was sure he would find the solution, and then he would be admired and worshipped by everybody as a new Messiah. He separated the Indonesian people into three categories: Moslems, Nationalists and Marxists. He did all this because he believed that he was destined to be the savior of his country and therefore prayed in his own way for the safety of his life and the greatness of his person.

Soekarno's deep and indestructible belief in his destination allowed him to patiently undergo the humiliation by the Dutch and later by the Javanese. This belief allowed him to persevere and be tough in politics. His perseverance was the primary factor which sustained him and enabled him to surpass other leaders at the time who were better educated than he, but who did not have the bulldog-like perseverance so necessary for a long struggle like the fight for independence. Soekarno fought hard for leadership and was always a genius in exploiting the right moments in time with his oratorical brilliance.

Soekarno was undoubtedly a great orator. Even before he assumed the presidency of the Indonesian Republic, he was capable of bewitching whole gatherings with his speeches. His language was not too pure and often outright crude, but his use of the language, his intonation and the gestures he made at the right time were flawless. His appearance was impressive. In front of the common people who were captivated by his charm, exuberance and delivery, Soekarno was in his element (Hanifah, 1972, p. 76).

Indonesia's inaugural President often used animal symbolism to convey his feelings during the revolutionary years under the archipelago's Japanese occupation. From his pre-war writings, the locals knew Soekarno considered Japan the modern imperialist of Asia. So, during this period he coined his famous metaphor: 'Under the blanket of the Rising Sun the Chinese dragon co-operates with the white elephant of Thailand, the caribou of the Philippines, the peacock of Burma, the nandi cow of India, the hydra snake of Vietnam and, now, with the banteng buffalo of Indonesia, in ridding our continent of Imperialism'.

To the Indonesian mind this was clear. It meant the occupied territories were united in the desire to exterminate aggression, not by co-operating with the Rising Sun, but rather by co-operating under the Rising Sun (Soekarno, 1965, p. 179). The Japanese were pleased with Soekarno's oratory and considered it purely a vehicle to keep the vanquished in line. Little did they know just how influential and overwhelming Soekarno would prove to be, especially against the Dutch and Japanese.

Given that he was Soekarno, the man who really could enchant the masses into feeling as one, the masses forgave him for his constant boasting. He was really an orator of exceedingly great strength. Whether one heard his speeches and stories once or multiple times, one could not help being overawed and overwhelmed by his thundering voice and absolute conviction. After all, he was charming, calm and fatherly. If he wished, he could be very disarming and pleasing. He was constantly aware that he had that kind of influence on his listeners who believed Soekarno was indeed their Savior. In his autobiography, Soekarno was quoted as saying:

I learned to grab my audience's attention at the very beginning. I not only grabbed it, I held it. They listened spellbound. A shiver went through me when I first discerned I embodied the kind of power that could move masses. I made my points simply. My hearers found them easy to grasp because I relied on descriptive terms rather than facts and figures. I appealed to the emotions ... 
They looked up at me as I spoke. They stared at me adoringly, eyes open wide, faces turned up, drinking it all in trustingly, expectantly. It seemed apparent I was becoming a great public speaker. It was in my blood (Soekarno, 1965, p. 179).

\section{President Soekarno and the Dawn of his New Nation}

The combination of Soekarno and Hatta during the revolution and initial years of the Republic of Indonesia was indeed a fortunate one. Soekarno alone could not have brought about the revolution, but in union with Hatta he was neutralized. Soekarno, the dreamer of great things to come, the man of the unbridled imagination, could be a great danger in a real crisis, just because he was full of wishful thinking and was a credulous person if only you could please him the right way.

Soekarno's vanity, in fact, made him from the very beginning a bad security risk. But Soekarno was undeniably the more popular and charismatic man among the masses because he had been known for so long. His name had already become a legend. Hatta, on the other hand, was strict, cool-headed, realistic and practical. He was a scholar, an economics expert, a pragmatist_essentially the right man to have beside Soekarno. According to Soekarno:

I never thought of mundane things like money. Only people who have never breathed the fire of nationalism can concern themselves about such trivia. Liberty was the food I lived on. Ideology. Idealism. The nourishment of the soul. That's what I fed on. I myself lived in rags, but what did it matter? Pulling together my party and my people, that's all I lived for ... I formulated my people's hidden feelings into the political and social terms which they would have spoken themselves if they could. I called to the old to remember their sufferings and to see them redeemed. I called to the young to think for themselves and to labor for the future. I became their mouthpiece ... Soekarno, the Great Ear of the Indonesian people, became Bung Karno, the tongue of the Indonesian people ... You can force a person to stand, but you cannot force him to smile trustingly or gaze admiringly or wave at you happily. I call upon humanity to examine the upturned faces of my people when Bapak speaks. They are smiling at me. Praying for me. Loving me. This no government can force (Soekarno, 1965, pp. 120-121).

Draping himself in nationalist clothes, Soekarno used strident rhetoric and nimble politicking to strengthen the executive branch and keep actual and potential opponents off balance. Foreign policy took a decidedly anti-western tone. Soekarno intensified efforts to wrest control of West Papua from the Dutch and launched an ill-fated military campaign against Malaysia to protest the establishment of the Malaysian states of Sabah and Serawak on the island of Kalimantan. Relations with Beijing and Moscow improved while ties with Washington D.C. increasingly soured, not least because of CIA support for the PRRI rebellion in West Sumatra.

For Soekarno, still imbued with notions of revolutionary grandeur, the economy took a back seat to the political struggle. In a famous speech on 25 March 1964, Soekarno told the United States to "go to hell with your aid". Nine months later he pulled Indonesia out of the United Nations in a pique against the latter's admission of Malaysia as a member state. "To intoxicate the masses until they were heady with the wine of inspiration was all I lived for. To me this was elixir. When I speak about my land I 
become excited. I become poetic. I was lyrical. I literally am overcome and this is transmitted to my listeners" (Soekarno, 1965, p. 82).

Notwithstanding that Marxism was arguably incompatible with the religiously affiliated Indonesian people, it was suggested in 1950 that Soekarno should have a party of his own. His answer was that he knew that whatever he believed in, the people would believe in too. Soekarno believed that in an election in which his ideas would be put at stake, he would win the majority of people to his side. He maintained that he did not need a party because the people, regardless of their own party allegiances, would follow him because he was Soekarno, their real leader (Hanifah, 1972, p. 5). After all, Bung Karno was a man not easily frightened, not easily beaten, and certainly not easily ousted from the Presidential Palace. But perhaps it was at this point in time that Soekarno's vanity started to get the better of him.

People could rightly say that Soekarno was a frustrated man. During all his speeches, he became fiercer and fiercer, to an extent where it looked as if he was trying to surpass himself. He often appeared obsessed and probably could not help saying the things he did say. Often contrary to the opinions he expressed in a calmer mood, many wondered whether he really meant what he said while delivering many of his speeches. Notwithstanding the mistakes Soekarno made as President, it cannot be denied that he really was the savior of his country and it is this honor which people cannot and should not deprive him (Hanifah, 1972, p. 204).

\section{Language, Persuasion and Great Oratory: A Comparison Between Soekarno's and Soeharto's Style}

Virginia Hooker once examined the very distinct styles of communication ${ }^{7}$ employed by Indonesia's founding President, Soekarno, and his long-standing, recently retired successor, Soeharto. While the former was considered poetic, charismatic, informal, even chaotic, the latter showed less compassion and militaristic tendencies in many formal and impersonal deliveries. While these rivaling manifestations were arguably indicative of the respective political environments in which these leaders found their country at the time, I believe their mannerisms and methods of communication reveal more about each man's upbringing, attitude and lifestyle.

One way in which the differing styles employed by the nation's first and second Presidents were exposed was the Independence Day Speeches. For instance, Soeharto's speech assessed key events of the past twelve months, proposed future goals and was directed at the Indonesian nation in its entirety. He would pay tribute to the significance of the 1945 Constitution and more contemporary agendas. Moreover, Soeharto would discuss the strength of productivity, industry, economic development and foreign policy as well as encourage the nation to strive for success and embrace the New Order's endeavors. On the other hand, however, Hooker makes reference to the fact that Soekarno was more concerned with presenting his own policies than with national policy

\footnotetext{
7 In the Oxford Encyclopedic English Dictionary, the term communication means [a] the act of imparting, esp. news. [b] the information etc. communicated. [c] a means of connecting different places, such as a door, passage, road, or railway. [d] social intercourse. [e] the science and practice of transmitting information esp. by electronic or mechanical means. [f] the means of transport between a base and the front. $[\mathrm{g}]$ a paper read to a learned society.
} 
during his Independence Day Speech. She argues that Soekarno's addresses were unplanned, unstructured, lacked an underlying theme and concerned merely the distant and recent past.

When addressing the nation, Soeharto often used the pronoun kita, the participatory and all-inclusive 'we'. He spoke with full authority, without intimacy and confidentiality, unlike his predecessor. Soeharto's use of memper- verbal prefixes and lebih dari pada itu (English: 'more than that') before a verb, although not surprising, was intriguing and to a certain extent, unbelievable. However, any ambiguity and argument implied by the audience would always be subsumed by Soeharto's confident tone and non-negotiable stance.

Notwithstanding his unmistakable authority as well, one characteristic evident in the speeches delivered by Soekarno, and not his successor, is the way he drew the audience close to him through references to shared experiences. Whereas Soeharto used monologue ${ }^{8}$, the role of language itself, through dialogue ${ }^{9}$, was obvious during Soekarno's time. He not only persuaded and inspired his audience, but emotionally entangled and even captivated them. He invited negotiation and argument when Soeharto did not.

Critics, however, such as Hooker allege that there was no sense of order, no rational argument nor controlled direction in Indonesia's founding-father's addresses. The element which enabled his style to succeed was that his delivery was 'inimitable and unforgettable'. Soekarno's speeches were undeniably 'personality-based' while Soeharto's were more policy driven and remembered only through repetition and cliché.

Stability has been viewed as the engaging quality of Soeharto's New Order and the underlying difference between both Presidential regimes. However, it must be noted the threat of the archipelago breaking up, the West's endeavor to disallow the spread of communism and the economic turmoil that followed as a result of independence, all impeded Soekarno.

According to Hooker, stability is a quality valued highly by Javanese society. Soeharto's Kromo (High Javanese) style revealed that he was in authority, whereas Soekarno's Ngoko (Low Javanese) style suggested otherwise. Soekarno's over-confidence, flamboyance, aggressive posturing, and individualism were not in keeping with the Kromo paradigm. This is in spite of the fact that both leaders were Javanese and Soekarno came from a more upper-class background than his successor. Each, however, assumed a contrasting aspect of 'Javaneseness' for his public persona and platform (Hooker, 1993, p. 75).

I think that as an Indonesian constituent, Soeharto's endeavor to progress and keep developing the Indonesian economy and society alike, without corruption, would be considerably heartening and well-received. As a public speaker, however, Soekarno's confident, enthusiastic and awe-inspiring deliveries would also drive me to greater heights. A potential leader with both Soekarno's and Soeharto's better qualities is the very person required to lead the Indonesian archipelago. B.J. Habibie does not appear to be of that mould.

\footnotetext{
8 In the Oxford Encyclopedic English Dictionary, the term monologue means [a] a scene in a drama in which a person speaks alone. [b] a dramatic composition for one performer. [c] a long speech by one person in a conversation etc.

9 According to the Oxford Encyclopedic English Dictionary, the term dialogue means [a] conversation. [b] conversation in written form; this as a form of composition. [c] a discussion, esp. one between representatives of two political groups. [d] a conversation, a talk.
} 


\section{Conclusion}

There is no doubt that Soekarno's confident, enthusiastic and awe-inspiring deliveries drove Indonesians to greater heights. Soeharto and Habibie, however, would not be justified in thinking that they achieved the same. The time will reveal how charismatic Gus Dur is and how enthusiastic he will be to use language effectively. Virginia Hooker's article shows just how powerful language can be. Effective use of language may yield Gus Dur continued success and acclaim whereas ineffective use may ultimately signal an unfortunate fate for Indonesia's fourth president. It may be the very thing that leads to his downfall.

Paul Lyneham, a political commentator, argues that the general charisma shortage in the present Australian Parliament does leave the Australian people all the poorer. The same could be said of Indonesia during Soeharto's New Order regime. According to Lyneham, charisma is the essential difference between a mere politician and a statesman: the latter can inspire and unite a community and paint a vision to get people to fall in behind it, while the former generally fails in this regard. Nobody in Indonesia has ever inspired such a conflict of emotion as Soekarno.

Soekarno was cursed like a villain and worshipped like a god. He admitted to having an ego and justified it by welding more than thirteen thousand islands into a nation. $\mathrm{He}$ was vain, but more so appreciated, and so often applauded merely for his theatrical nature and accomplished oratory skills. Soekarno was without a doubt one of the greatest charismatic statesmen the world has ever seen. Notwithstanding his affiliation with communist ideology, Soekarno will long be remembered for his ability to wisely assimilate performance and language which undeniably facilitated his long-standing position of power in the Indonesian Republic's short but dramatic political history.

\section{References}

Anderson, Ben. (1991). Language \& power: Exploring political cultures in Indonesia. Ithaca, N.Y.: Cornell University Press.

Hanifah, A. (1972). Tales of a revolution. Sydney: Angus and Robertson.

Hooker, Virginia. (1993). New Order Language in Context. Culture \& society in New Order Indonesia. Kuala Lumpur: Oxford University Press.

Lev \& McVey. Editors. (1996). Making Indonesia. New York: Cornell University.

Mani. (1986). The story of Indonesian revolution 1945-1950. Madras: University of Madras.

Porter, L. \& S. Williams. (1999). The It Factor. The Sunday Age Magazine 7 November 1999. Melbourne.

Soekarno. (1965). Soekarno: An autobiography. Hong Kong: Gunung Agung. 